\title{
THE EVOLUTION OF THE EXTERNAL CONSULTANT INVOLVEMENT IN HUMAN RESOURCE MANAGEMENT IN EASTERN EUROPE (1990-2007)
}

\author{
József Poór, Imola Józsa \\ J. Selye University, Komárno, Sl ovakia - Szent István University, Gödöll, Hungary
}

\begin{abstract}
This paper aims to analyze the evolution of Human Resource (HR) consulting in transitional economies of Eastern Europe (EE) from the political changes until economic crisis 2008. This article provides insights into the specific socio-economic environment and HR practice of the region. Following Markham 's (1999) model the authors analyze specific characteristics of four typical ways of external consultant involvement: informative-benchmarking, design, change and organizational learning consulting in this region. In general, before the political changes at the end of the 1980's, in most EE countries, consulting service was rendered by sector research institutes controlled by the state or by different ministries. Consulting approaches in EE countries were predominant similar to the school of scientific management. HR Consulting hardly existed that time. Since changes in the regime's consulting linked to privatization, firm restructuring and development has been developing significantly in all countries. HR consulting has become a significant development tool in the region.
\end{abstract}

Keywords: Human Resources, Consulting, Eastern Europe, Ventures in the CEE countries, New consultancy landscape in CEE region, Change consulting

DOI: http://dx.doi.org/10.15549/jeecar.v2i1.70

\section{INTRODUCTION}

While other practices or professions trace their roots back several centuries, management consulting is less than 150 years old. We can find their early origins at the end of the $19^{\text {th }}$ century. "Advisory practices" began in the 1860 s in the United Kingdom.

In Eastern Europe, after 1990, the large U.S. accounting and management consultancy firms entered each country and then aggressively pursued business on their own or with partners. Despite these, some local small consultancies began to flourish.

Generally speaking, consulting is "a knowledge-based service, it can be sold and bought, but it cannot be dropped on your foot, and it cannot be displayed in a shop-window. The service of a consultant is often intangible, hard to store and/or transport, and difficult to demonstrate its advantages to potential clients" (Miles, et al., 1999:3). In respect of such services we need to highlight the following four important aspects in:

- Human capital and knowledge intensive,

- High degree of intangible activities and services,

- Difficulties in standardization,

- Intensive interaction between consultants and clients.

The Human Resource area is considered as one of the fastest growing areas of the management consulting (further consulting). Effective Knowledge Management (KM) is inevitable for a well-managed HR consultancy. KM involves all the viewpoints and activities needed to comprehend, use, and benefit from capital in the form of organizational knowledge (Allee, 1997; Martensson, 2000). KM is not a one-dimensional activity. It includes two major items (Polanyi, 1967). Knowledge, transferred by an HR consultant consists of two main types:

- Explicit knowledge can be transferred 
through such media as reports, books, archives, databases and groupware technology

- Tacit knowledge can be best transferred through personnel movement and the collaboration of individuals

In the consulting process, the consultant can fill two typical roles (Steele, 1975; Meister, 1993; Kubr, 1996; Niedereicholz, 1996, Curnow-Reuvid, 2003 and Kipping, K. and Clarck, 2014):

- Expert Resource Consultant, who suggests solutions based on his expertise and experience discusses with the clients the correctness of these solutions and gives assistance in the implementation. Expert consultant transfer typically tacit knowledge. This role is very typical in informationbenchmarking and design consulting. Drucker (1979) called as knowledge-provider the management consultant in his publication even in a quarter century ago.

- Process/People consultant, who assists the client in searching for solutions with methods that facilitate and raise creativity of the client's employees; and therefore, the clients themselves will be able to implement solutions. The root of this approach goes back to Kurt Lewin (1933, 1948 and 1973). This role has traditionally been demonstrated by organizational development and change consulting (Schein, 1999 and 2002). The Process Consultant typically transfers tacit knowledge.

It is also an important question what the client gains from the consultant. What kind of products and services does the consultant provide? The authors have found several general answers to this in the literature. Among others we need to quote Markham's approach (1999) on the nature of management consultancy, according to which consultancy interventions can be involved at a number of levels: benchmarking, planning, change and learning.

It is al so worth mentioning why consultants are employed in different HR fields. It is proper to ask, whether there is anything specific in this branch compared to general consulting. Various authors agree that HR consultants are chosen on a professional basis in this area as well (Cooley, 1994; Fenn, 1994). Besides the above indicated reasons clients request help from consultants if professional independence, or a catalyst is needed, or if resources are missing, or eventually unpleasant decisions have to be justified (Wood, 1985). It is safe to say that if characteristics of human resources (age, competence, experience, remuneration, etc.) are linked to a certain person, then the level of confidence is increasing. And for this reason the need for an independent, external expert is increasing, too.

In organizations, with usually a headcount of less than 80-100 persons, we can hardly find these partners (Mathis\&Jackson, 2003). Typical clients of HR consultants are the experts working in the field of HR at big companies or increasingly at public sector (UN,2005). Some multinational companies (MNC) clearly designate those consultants that can be used by their subsidiaries. Other MNCs are more decentralized, and they don't insist on involving those consultants locally that are also employed by the headquarters (Dowling\&Welch, 2004).

\section{Role of HRM in Eastern Europe}

Differences may be observed between the levels of development in the HR practices of different Eastern European countries. These may be attributed to differences in traditions, the level of economic development, and the level of centralization in the previous economic and political systems of various countries. In these countries; the characteristics of modern HR within the framework of their previous systems were only present in small sections.

Typically; approaches similar to the school of scientific management - mentioned earlier were predominant.

Generally speaking, HRM activity in most East European countries, prior to the changes that took place at the end of the 1980s, was very tightly controlled by the state. Personnel(meaning management-) related issues were under the close control of the party and heads of the state.

The key positions in companies were closely monitored by the party and by state bureaucracy. Management was not considered as a profession (Cakrt, 1993) and decisions regarding promotion were not based on performance assessment (Pearce et al, 1993). In several cases; the selection of specialists and personnel-related decisions were greatly influenced by party- and government politics and objectives, and the party instructed company directors to blend together the aspects of individual and collective leadership. 
The traditional Eastern European human resource management philosophy followed an industrial, production economy bias (Kovári, 1995). Social goals focused on the production of industrial and consumer durable goods, applying bureaucratic processes of increasing specialization of labor. Consequently, broader job descriptions and higher personnel commitments were new to employees working in Western styled joint ventures.

During the 1990's the focus within Eastern European companies was on assisting the organization in making the transitions associated with privatization. Organizational restructuring and establishing new human resource processes, policies, and practices were the order of the day. During the subsequent years, the focus has increasingly shifted toward a continuous improvement approach aimed at helping the organization develop and on assisting individual employees develop through coaching.

The literature addresses several classifications related to the transformation and development of the HR profession. From our aspects we have to mention, that besides its traditional administrative and collective bargaining characteristics, various authors describe HR's increasing strategic and consulting role as well. The work of HR experts - in case of introducing various human resource systems or solving tasks related to organizational development - shows many similarities to the contribution of external consultant. Based on the above, some say that in these cases HR experts act as internal consultants (Amstrong, 1999; Ulrich, 1997; Poor, 2006).

The management of industrial relations is considered to be a unique field of HRM. The number of unionized employees varies widely in different regions of the world. The level of unionization depends on traditions, legal and political institutions and the development of trade unions. While, in ex-Communist countries, unionization in state-owned companies, public sector and in private companies in certain industries is still quite high, reaching $80-90 \%$ in the U.S., in Western Europe and in foreign firms dominated firms and industries in the region the number of unionized workers has been falling dramatically.

Every beginning is difficult in management consultancy in the EE environment

When the Iron Curtain and the Berlin Wall came tumbling down at the end of 1980s, the management consulting industry appeared in the EE region relatively quickly. The local subsidiaries of MNCs offered management consultants an excellent marketing opportunity. (Gross et al.,2004). For example in Eastern Europe the use of HR consulting service exceeded $15-24 \%$ of firms surveyed, far beyond the US or Western European average $(10,8 \%$ ) (FEACO, 2008; Janko,2006). This difference may stem from the fact that this region has no tradition of Western like people management and training. As stated earlier, political stability was a long-standing substitute for managerial capability under the state socialist regime - and now this profession needs additional support (FEACO, 2003).

A growing number of scholars and practitioners claim that privatization does not automatically improve the effectiveness of government, companies and social welfare systems. On the contrary, it may well increase opportunities for corruption and bribery. When a company is being privatized or governed by Western-like business law, there is no guarantee that the values and mindsets of the people will change along with it. The adoption of all the financial, legal, technical and sales frameworks in a privatized local company or in firms with foreign participation represents only the first stage in the creation of a Western-like enterprise. Once all this is in place, one must start to consider how to get the people and the organizations to perform in a competitive way. The best financial infrastructure in the world will not change companies around from command economy to market economy if the people and the organizations do not deliver.

There are more and more signs that in these countries, apart from financial and privatization consultancy, other areas of consultancy business will also emerge. Until the end of the 1990's the role of the consultant in the consultant-client relationship was basically and in many ways similar to that of a supplier who provides different products and services. Over a shorter or longer period the consultant drafted a rather extensive report, which together with an accompanying letter or in the framework of a presentation, he "delivered" to the client. During the last two to three years this relationship has gradually become a mutual partnership, aimed at the effectiveness of the client.

There are an ever-increasing number of jointly 
or wholly owned foreign ventures in the CEE countries. They employ Western management philosophies, systems, and procedures. The application of accepted management practices and the proper management of human resources are important to these multinational corporations (MCS). It should be noted, however, that the CEE economies continue to suffer from the values, habits and business practices, which were inherited from the former system. In particular the egalitarism, low respect for supervisors, low work ethics and the party influences of the former economy, are still present and will require more time and effort to dismantle. Consequently, many multinational firms simply try to avoid these problems by hiring young people who are not overwhelmed or influenced by the factors described above.

In Central and Eastern Europe, like in the rest of the world, the accountancy-based firms are predominant. They are highly represented in all CEE countries and are considered as pioneers. They are major competitors of the Management Consultancies. There are also other important competitors. The Austrian, Swiss and German small and medium-sized firms have contributed to the creation of a wholly new consultancy landscape in this region. These firms are culturally quite close to the region, and when the opportunities presented themselves, they have entered the market.

The first representatives of foreign consultancy firms appeared in Hungary already at the beginning of the 1970's. They were attracted at the time by the launch of the World Bank's restructuring programs. The first joint ventures in consultancy were established in the mid1980's, and were mainly co-operations with German, Austrian and Swiss companies. From the end of the 1980's, the number of consultancy firms of Anglo-Saxon origin started to expand.

The top traditional consulting firms (McKinsey\&Co., Boston Consulting Group, HayGroup, Roland Berger, etc.) have set up offices in most cases only in one or two CEE countries, or have managed their projects in the region from their Western-European offices (Bain, Booz, Allen \& Hamilton, Mercer, TPC, Whyte, TPC, etc.)

However, a consultant working in an international business environment soon realizes what is good in San Francisco, may not work in a Hungarian family venture.
Foreign capital inflow played an important role in the now widespread usage of outside consultancy among enterprises of these countries. Companies differ in their number of employees and sales but also in their willingness to hire consultants: bigger companies (higher number of employees and higher sales) are more likely to employ consultants than smaller ones.

Large, international companies like to employ consultants in order to solve their management problems (Sturdy,2011). Some international companies determine for their whole group which consultants to work with, while others are more decentralized and independent. They do not stick to consultants who are employed by the central office, but choose among local offices. Both, local and international companies, employ management or Human Resource Management (HRM) consultants for different problems related to HRM.

\section{FIELDS OF HR CONSULTING}

In this section, the authors give an overview on the typical consultant intervention methods in relation to HR - based on Markham's model:

\section{Information-benchmarking consulting}

Benchmarking is a constant and systematic process for measuring competitiveness, and also those best practices that an organization is most interested in. This measurement - as described by Evans - analyzes, "how the company analyzed is doing (i.e. reward, employee satisfaction e.g.) what others are also doing" (Evans,1977:14.)

For the client the basic aim of this type of consulting is to get answers for his questions, based on the data collection and analyses performed on general or special samples inside or outside the company (Markham, 1999). Such questions can be: What is the general practice in terms of variable pay? What is the level of absence rate? What kind of salary increase do the competitors plan to make in the future? How satisfied are the line managers with the HR work? e.g.

In recent years the benchmarking method was applied in relation to many other HR areas. Without aiming to give a full picture, the following surveys and analyses can be highlighted, that were made for collecting information and drawing comparisons:

- Surveys and databases analyzing HR practices, Remuneration and motivation 
surveys,

- Comparisons based on general and specific competency databases relevant to positions and grading,

- Database comparisons and specific analyses regarding organizational and team culture,

- Analyses of employee attitudes and satisfaction etc.

Despite the above problems benchmarking research, surveys and other similar empirical analyses will still remain important for the business world in the future. As changes are accelerating the companies specialized in making these surveys will have to satisfy their clients' needs more quickly, and new technologies and esolutions will probably provide a lot of support in this.

\section{Design consulting}

The essence of this consulting practice is that the consultant works out a system design of the HR method or process that satisfies client's needs the most, and also implements it, if requested (Markham, 1999). Here, the main objective of consulting is to facilitate the planning and implementation of such formal systems that ensure a more efficient and more effective utilization of human resources of the organization to support the achievement of organizational objectives (Mathis-Jackson, 2003:4).

This instrumental approach is characteristic of the administrative, the collective bargaining, and partly the strategic HR, as well. Multinational companies have a significant advantage compared to local companies in the introduction of various HR tools and methods. Hiltrop (1991) had described this fact already at the beginning of the 1990's. Local companies and the public sector are pioneering rather in collective bargaining, and not in applying the latest HR methods. Of course, this statement can be challenged, like all general trends. We know several state-owned companies where HR practice is well ahead of that of some multinational companies, but the lack of financial resources, or the constantly changing business management or organizational concepts often hinder the application of modern methods and procedures, even if intentions are good. The situation in Eastern Europe is especially bad, as Smells do not care about the development of their HR practices.
Scholars and professional consultants have argued about possible sources of the modern HR tools for public sector in our region. Regarding this issue it can be identified two major approaches as follows (Dudás et al, 2003):

Internal approach: Many practitioners assume that the problems and opportunities can only be solved through internal resources. The new HR models and solutions can successfully develop within the public sector.

External approach: Supporters of this orientation believe that the renewal of the public sector can be rooted in borrowing from a number of other areas of research as well as from the private sector to find new solutions, places the public sector in its cultural and political environment, and sees the role of public manager as an active and motivating agent. Nevertheless, it also recognizes that many of the more radical reforms attempted in countries such as New Zealand and the United Kingdom are too ambitious and present real dangers for most transitional countries; simply getting the public administration to execute the will of its political masters is often a challenge in itself.

In this respect, it is important to note that more and more experts recognize the issues and dangers of one-side approach. Many authors assert that, instead of criticizing the internal or external approaches, we should act and reap its benefits (UN,2005).

\section{Change consulting in $\mathrm{HR}$}

We can talk about this type of consulting, if the aim and the implementation methods are only broadly outlined (Markham,1999) and the implementation affects human, formal and informal, and operational subsystems of a given organization (Katz-Kahn,1978; Morgan, 1986, Nadler et al,1992; Burke,1993).

The organizational success - and thus the main emphasis of consulting - is moving from the creation of strategies towards successful implementation of changes. In this model the main objective of consulting is the creation of an appropriate relationship between partners, and also the creation of a force field, where forces supporting change are stronger than forces obstructing this change (Cummings and Worley, 1993).

Change consulting is a new phenomenon in the region. Since the regime changes it has undergone several development stages. In 90's it 
related mostly overcoming differences in value and motivation between old and new systems. It orients typically tow ard added-value generation.

\section{Organizational learning consulting in HR}

This type of consultant involvement aims to establish organizational learning capabilities with external help that can later serve as a basis for self-development (Markham, 1999). This approach is characteristic of the 'coach' development phase of HR. Instead of the limited bureaucratic structures this management practice supports the implementation of solutions with fewer boundaries.

The evolution of organization learning consultancy in the region followed the below written pattern:

Prior to the '90s, lengthy tenure and relevant work experience were highly regarded, and relative to other job categories, production and technical positions were well-respected, but changes in the political environment, followed by privatization and significant foreign investment, changed this trend. In the late ' 90 s, production and technical positions significantly decreased in prestige terms, whilst sales and marketing positions rose in the rankings. Key subjects of organization learning had to support adapting key technical know-how and skills on fields of client orientation, people management and basic technological processes.

Contemporary HR consulting on this field is starting to leave behind the instrumentalist, Taylorist, scientific management approach and practice, which used to be characteristic in this region, too. The notions of Maslow's and Herzberg's need- and dual-factor theories; the motivation researches of McClelland and cognitive approaches (expectation, objective, behavior selection and market value) are becoming increasingly well-emotions must be reinvigorated and the economy must be made more satisfying. We must al so recognize this new requirement, which at the same time creates new opportunities to elaborate practical solutions.

One the key results of learning consulting that the workforce of the advised company can possess new mindset. Experienced HR consultants (Kasigic, 2004), believe that the new generation of EE executives have already raised the level of their management skills to Western standards.

\section{CONCLUSION}

Over two decades (1990-2007), the relationship between consultant and client has changed significantly in Eastern Europe.. Within traditional consulting the client and the consultant were not equal partners. The consultant, especially Western consultants, knew much more about the methods and processes, than the client who employed him. In the meantime, however, managers and professionals made up for this shortfall. Clients now expect consultants not just simply transfer the knowledge and documentation related to a given HR methods and procedures, but also to develop an organizational capability that enables the company or public institution to efficiently apply the tools implemented, when the consultant's assignment is finished.

The field of HR Consulting in EE is beginning to become effective tools for consultants and the companies who use consultants. Markham's four concepts in consulting are being phased in to EE consulting because of Western consultants being hired in the EE region. Benchmarking, Design consulting, Change, and Organizational Learning are being integrated into the consulting process in the EE. Effective change is being put in place by consultants whose companies accept the advice of the consultant.

HRM has begun to receive more consideration in the EE based consultants to introduce new methods on particular HR fields. All the phases of HR consulting are being implemented to ensure a positive training result and a more effective and productive EE workforce. Western consultants are bringing their training and delivering the advice to the EE. As a result, more effective management in the EE has increased the level of cooperation and communication among the divisions of organizations.

The outlook is good for the growth of the consultancy business. In the future, management consultancy is going to be an integral part of such service offerings with consulting opportunities in information technology and outsourcing followed by operations, strategy, and human resources as well. Consultancy will remain a significant practice as well as asserting itself and more as a profession

This analysis highlighted the major trends in pre-crisis of 2008 for general consulting and in HR consulting fields in the CCE region. Because of the 2008 crisis, a lot has changed in these fields. 
Further research is needed for the effects of the 2008 crisis in the EE region in all consulting operations.

\section{REFERENCES}

Alas,R. and Svetlik,I. (2004).'Estonia and Slovenia: building modern HRM using a dual ist approach', in Brewster, C., Mayrhofer,W., and Morley,M. (eds.), Human Resource Management in Europe: Evidence of Convergence? London; Elsevier.

Allee,V. (1997). '12 Principles of knowledge management', Training \& Development, 11: 71-74.

Amstrong, M. (1999).'Human Resource Management Practice', London; Kogan Page.

Anderson, C. (1997),'Values-Based Management' Academy of Management Executive, 4: 2546.

Arah,J. (2006). 'General Trends in Management Consulting in Central and Eastern Europe' (Proceeding) Prague; FEACO-ESCO.

Curnow, B. and Reuvid, J. (2003). The International Guide to Management Consultancy. London, Kogan Page.

Brewster,C., Mayrhofer,W. and Morley, M. (Eds.) (2004). 'Human resource Management in Europe: Evidence of Convergence? Oxford: Elsevier Butterworth-Heinemann Publishers.

Budhwar, P.S. and Debrah, Y.A. (2001).'Human resource management in developing countries'London; Routledge.

Burke, W.W. (1993). 'Organizational Development: A Process Learning and Changing'Reading (MA), Addison-Wesley.

Cakrt,M. (1993).'Management education in Eastern Europe: Toward mutual understanding'Academy of Management Executive,4: 63-68.

Clark. T. and Fincham,R. (2001). 'Critical Consulting New Perspectives on the Management Advice Industry Oxford; Blackwell.

Claessens, S. and Djankov, S. (2002).

'Privatization in Eastern Europe', Journal of

Public Economics, March: 307-324.

Cooley, M.S. (1994).'Selecting the Right

Consultant', HR Magazin,August: 100-103.

Cranet (2006).'Cranet Survey on Comparative

Human Resource Management', Cranfield;

Cranfield University.

Cummings, T.G. and Worley, C.G. (1993). 'Organization Development and Change', St. Paul; West Publishing Co.

Dowling, P.J. and Welch, D.E. (2004).

\section{'International Human Resource} Management', London; Thomson.

Drucker, P.F. (1979). Why Management Consultant? in Zimmer, M. and Smiddy, $\mathrm{H}$. (eds.) The Evolving Science of Management, New York; AMACOM.

Dudás, F., Karoliny, M-né., László, Gy., Lévai, Z. and Poór,J. (eds.) (2003). Introduction into Human Resource Management in Public Sector. (In Hungarian) Budapest; Public Sector Institute.

Evans, A. (1977). 'Benchmarking', (In Hungarian) Budapest; Közgazdasági és Jogi Publishing Co.

Farkas, F. (2004).'Change Management', (In Hungarian) Budapest; Közgazdasági és JogiKerszöv Publishing Co.

FEACO $(1999,2000,2001,2002,2003,2004,2005$, 2006, 2007). 'Survey of the European Management Consultancy Market', Brussels; FEACO-Federation European Management Consulting Associations.

FEACO-SESMA (2004). 'Building a Competitive Knowledge - Based European Economy The Role of Consultant', (Conference Proceeding) Athens; FEACO-SESMA, 21-22 October.

FEACO- VTMSZ (2001).'Contribution of Management Consultants to the Development and Renewal of Emerging Countries of Europe', Budapest, (Conference Proceedings) FEACO-VTMSZ, June $1^{\text {st }}$.

Fenn, D. (1994). How to Distinguish Dolphins from Sharks. Personnel Management, August: 32-35.

Garvin, D. A. (1973).'Building a Learning Organization', Harvard Business Review, July-August: 78-91.

Gross, A., Poór, J. and Roberson, M. (2003). 'Management Consulting in Central Europe, An Overview' C2M-Consulting to Management Journal, March: 33-39.

Gross, A. and Poór, J. (2008). 'The Global Management Consulting Sector' Business Economics, October: 69-78.

Gross, A., Holzblatt, M., Javal gi, R., Poór, J. and Solymossy, E. (2013). 'Professional Occupations, Knowledge-Driven Firms, and Entrepreneurship: A National and Regional Analysis' Business Economics, 4: 246-259.

Hiltrop, J-M.(1991).'Human Resources Practices of Multinational Organizations in Belgium', European Management Journal, 4: 404-411.

I.W. (2004).'Relocation from GermanyInternational Comparison', (In German) Köln (Cologne): Institute für Weltwirtschaft. 
Karoliny, M-ne., Farkas, F., Laszlo, Gy.and Poor, J. (2003). 'Human Resource Management', Hungarian) Budapest, Közgazdasági és Jogi Kerszöv Publishing Co.

Kasagic, M. (2004).'Human capital as growth factor', (Conference proceeding) Vienna; $2^{\text {nd }}$ Symposium Central and Eastern Europe Connecting Corporate and Academic Group, 18-19 November.

Katz,D. and Kahn, R.L. (1978).'The Social Psychology of Organizations', New York; John Wiley and Sons.

Kieser, A.(1995), Organizational Theories, (In Hungarian) Aula Publishing Co., Budapest.

Kindler J. (2002), "Rehabilitation of Emotions" (In Hungarian) In: Kocsi T. (Ed.), People based Economy, Válasz Publishing Co., Budapest.

Kipping,K. and Clarck,T.(2014), The Oxford Handbook of Management Consulting. Oxford: Oxford University Press.

Kotter, P.J. (1999), Change management. (In Hungarian) Közgazdasági és Jogi-Kerszöv Publishing Co., Budapest.

Koubek,J. and Brewster,C. (1995).'Human resource management in turbulent times: HRM in the Czech Republic', International Journal of Human Resource Management, 2: 223-247.

Koubek,J. and Vatckova,E. (2004).'Bulgaria and Czech Republic: Countries in Transition', in Brewster, C.,Mayrhofer, W. and Morley, M., 'Human Resource Management in Europe Evidence of Convergence?, London; Elsevier.

Kubr,M. (1993): How to select and use consultants, a client's guide, Geneva: International Labour Organization..

Kubr, M. (1996). Management Consulting Guide to the Profession, Geneva: International Labour Office.

Leonard-Barton,D. (1995). ' Wellsprings of Knowledge', Oxford; Harvard Business School Press.

Lewis, P.C.(2005). 'How the East Was Won', New York; Palgrave Macmillan.

Lewin,K. (1933). 'A Dynamic Theory of Personality', New York, McGraw-Hill Book.

Lewin,K. (1948).'Self-hatred among Jews. Resolving Social Conflicts', New York; Harper and Row.

Lewin,K. (1973).'Force Field Analysis', in Jones, J.E and Pfeiffer, J.W., Annual Handbook for Group Facilitators, San Diego.

Lippitt,G.and Lippitt, R. (1978).'The Consulting Process in Action', LaJolla; University Associates Inc.
Maister, D.H. (1993).'Managing the Professional Service Firm',New York; Free Press.

Manolescu A.(2003). 'Human Resource Management', (In Romanian), Bucharest; Editura Economica.

Markham,C. (1999).'The Top Consultant', London; Kogan Page.

Matensson, M. (2000).'A critical review of knowledge management as a tool', Journal of Knowledge Management, 3; 204-216.

Mathis, R. L. and Jackson, J.H. (2003). 'Human Resource Management', Mason $(\mathrm{OH})$; Thompson-Southwestern.

McCristy,N.(2002).'Creating a Learning Organization',Office Solution Magazine. February: 26-29.

Mercer (2006).'Global Compensation Planning Report', Geneva; Mercer Human Resource Consulting.

Miles, I., Coombes, R. and Metcalfe, S. (1999).'Services and Innovation Background', Paper for the 6 Countries Programme Workshop, Manchester; 22-23 April.

Morgan,G. (1986). 'Images of organization', London, Sage.

Nadler, D.A. (1997). 'Champions of Change', San Francisco; Jossey-Bass.

Niedereicholz, Chr. (1996).'Management Consulting' (In German) Munich; R. Oldenburg.

OECD/LEED (2005).'Business Clusters: Promoting in Central and Eastern Europe', Paris; OECD.

Pearce, J.L., Branyiczki, I.and Bakacsi,Gy. (1993).'Person Based Reward Systems Reward Practices in Reform Communist Organizations' in: Maruyama (ed.), Management Reform in Eastern and Central Europe, Dartmouth.

Pfeffer, J.(1994). 'Competitive Advantage through People', Boston; Harvard Business School Press.

Piispanen-Krabbe, T. K. (1990). 'Yankee Traders in the New Europe: Recent Experiences in the Eastern Bloc', International Executive,3: 2932.

Pléh Cs.,Kovács Gy. and Gulyás B. (2003).'Cognitive Neurology',(In Hungarian) Budapest; Osiris Publishing Co.

Polanyi, M. (1967). 'The tacit dimension', Garden City; Anchor Publishing.

Poór,J. and Gross, A. (eds.):_Management Consultancy in an Eastern European Dimension. Budapest: Economic and Law Publishing House (Közgazdasági és Jogi Könyvkiadó - Kerszöv). 
Poór J. and Roberson, M. (2003).'Global Development. Effectiveness of Human Resource Management at Hungarian Firms' (In Hungarian) Hungarian Management Review (Vezetéstudomány) 1: 13-19.

Poór, J. (2006).'HR in transition internationalization in Human Resource Management', Budapest; MMPC Publishing Co.

Poor, J., Roberson, M .and Gross, A.(2006).'Global Evolution: HR Effectiveness in Hungarian Companies at the Mid of the First Decade in $21^{\text {st }}$ Century', Berlin; (Conference Proceeding) VIIIth IFSAM Conference, September 28-30.

Poor,J, Gross,A., Farkas F., Roberson,M., Karoliny, Mne., and Susbauer, J.(2007). 'Human Resource Management in Central Europe: Policies and Practices', (Conference Proceeding) San Francisco; IBEC Conference, January 4-7.

Porth, S.J. and McCall, J. (2001).'Contemporary Management Theory and Catholic Social Teaching: Similarities and Difference', Review of Business, Fall: 8-16.

Schein,E.H. (1999). 'Process Consultation', Reading-MA, Addison-Wesley.

Schein,E.H. (2002).'Consulting: What Should it Mean?', in Clark, T. and Fincham, R. 'Critical Consulting', Oxford; Blackwell Business.

Senge,P.M. (1990).'The Fifth Discipline:The Art and Practice of the Learning Organization', New York; Doubleday-Currency.

Steele, F. (1975).'Consulting for Organizational Change',Amherst, University of Massachusetts Press.

Sturdy,A. (2011). 'Consultancy's Consequences? A Critical Assessment of Management Consultancy's Impact on Management' British Journal of Management, 22: 517530.

Sun,Q. (2003).'Economic globalization affecting economic development of East Asia', International Journal Asian Management. 113.

Suntari, R. (2001).'Organizing for the New Economy', CMA Management, 12.

Ulrich, D. (1997).'Human Resource Champions', Boston; Harvard Business Review Book.

UN (2005).' Unlocking Human Potential for Public Sector Performance', New York, United Nations.

Vatchkova, E. (2001).'The Speed of Changes Bulgarian Way to the Integrated European HRM. Vth Chemnitz Forum', Human
Resource Management in Transition, University Technology, Chemnitz, 21-23 March.

Vatchkova, E. (2004).'Competence-based Human Resource Management Training. HRM in a Knowledge Based Economy Ljubljana, 2-4 June.

Wood,D.(1985).'The Uses and Abuses of Personnel Consultants', Personnel Management, October: pg. 41. 


\section{ABOUT THE AUTHOR}

József Poór email: poorjf@t-online.hu

Dr. József Poór, is Professor of Management at Selye Janos University Komarno (Slovakia) and in Szent István University Hungary, He earned his Ph.D. from the Hungarian Academy of Sciences Budapest. He served as guest professor at five different US universities (PAMI-Honolulu, BellermineLouisville, EKU-Richmond, Saginaw-Michigan and CSU-Cleveland) and taught thirteen short summer semesters. He was senior manager (Managing Director, Country Manager and senior consultant) at different internationally recognized professional service firms (Mercer, HayGroup, Diebold) and at a private business school (International Management Center, Budapest). His scholarly publications have appeared in more than ten internationally referred journals. He wrote twenty five books and book-chapters in Hungarian, one book (Walter-KluwerComplex) and five book-chapters (AddisonWesley, Chapman\&Hall, Kogan Page, Prentice Hall and Routledge) in English and one book in Romanian alone or as co-author.

Ms. Imola Józsa, is PhD Candidate in Doctoral School of Management and Business Administration in Szent István University (Hungary). She has been awarded three degrees: the first one is in Information Technology (IT) Engineer (BSC) and she has specialised in Technical Management, as part of this Engineer programme. She has participated in Master's (MSc) Degree programme in Management and Leadership as well, and she has been awarded a Master's Degree graded with Excellent with Honours, and a professional qualification of Economist in Management and Leadership. And she has also got a specialisation in Human Management and Organization Development, as a part of a Master's Degree programme. Professional experiences: formerly she has been working as an insurance consultant and manager for several years in a MNC of an insurance sector in Hungary. She has been working as Personal Insurance Business Manager, Branch Manager and Business Unit Leader as well. 